\title{
JMS
}

P-ISSN: 2722-9270 ejournal.uksw.edu/jms

\section{Pembangunan Infrastruktur Jaringan Internet Murah Berbasis Gelombang Radio}

\author{
Bambang Widjanarko Susilo ${ }^{1^{*}}$ \\ Priyo Nugroho Adi ${ }^{2}$ \\ Siska Narulita ${ }^{3}$ \\ Andreas Tigor Oktaga ${ }^{4}$ \\ Priyo Wibowo ${ }^{5}$
}

1, 2, 3, 4 Program Studi Sistem dan Teknologi Informasi, Institut Teknologi dan Bisnis (ITB) Semarang 5 Program Studi Analis Kesehatan, Politeknik Katolik Mangunwijaya

A R T I C L E I N F O

Article history:

Received 15-09-2021

Revised 20-10-2021

Accepted 26-11-2021

Key words:

Covid-19, internet, online, gelombang radio

\begin{abstract}
A B S T R A C T
The Covid-19 pandemic has occurred for more than a year and almost all sectors have been affected by this pandemic. It was recorded on the official website Satuan Tugas (Satgas) Penanganan Covid-19, regarding the growth of Covid-19 cases in Central Java Province, showing that many deaths occurred in people aged 60 years, even $2.5 \%$ of children aged $0-5$ years are positive for Covid19. In the world of education, the Government urges all educational institutions to conduct online teaching and learning activities. Interaction and communication between students and teachers is done virtually through various applications. Supporting facilities that are no less important is the availability of the internet network. In Dusun Tanggulangin Desa Margosari Kecamatan Limbangan Kabupaten Kendal, currently there is already an internet network provided by internet providers, but the cost is still considered quite expensive by local residents. The level of internet access for online teaching and learning activities in Dusun Tanggulangin Desa Margosari is high enough because the number of residents with student status is large enough. In addition, the development of internet network infrastructure requires substantial funds. Based on these things, community service activities are aimed at " Pembangunan Infrastruktur Jaringan Internet Murah Berbasis Gelombang Radio di Dusun Tanggulangin Desa Margosari Kecamatan Limbangan Kabupaten Kendal". As a result of this activity, the surrounding community has easy access to the internet at a more affordable cost.
\end{abstract}

\begin{abstract}
A B S T R A K
Pandemi Covid-19 terjadi sudah lebih dari satu tahun ini dan hampir semua sektor terdampak pandemi ini. Tercatat pada website resmi Satuan Tugas (Satgas) Penanganan Covid-19, tentang pertumbuhan kasus Covid-19 di Provinsi Jawa Tengah,
\end{abstract}


menunjukkan bahwa kasus meninggal dunia banyak terjadi pada penduduk usia $\geqslant 60$ tahun, bahkan 2,5\% dari anak berumur $0-5$ tahun positif Covid-19. Dalam dunia pendidikan, Pemerintah menghimbau kepada seluruh institusi pendidikan untuk melakukan kegiatan belajar mengajar secara online. Interaksi dan komunikasi diantara para peserta didik dan pendidik ini dilakukan secara virtual melalui berbagai macam aplikasi. Sarana penunjang yang tidak kalah penting adalah ketersediaan jaringan internet. Di Dusun Tanggulangin Desa Margosari Kecamatan Limbangan Kabupaten Kendal saat ini memang sudah ada jaringan internet yang disediakan oleh provider internet, namun biayanya masih dirasa cukup mahal oleh penduduk sekitar. Tingkat akses internet untuk kegiatan belajar mengajar secara online di Dusun Tanggulangin Desa Margosari cukup tinggi karena jumlah penduduk dengan status pelajar atau mahasiswa cukup banyak. Selain itu, pengembangan infrastruktur jaringan internet membutuhkan dana yang cukup besar. Berdasarkan hal-hal tersebut, kegiatan pengabdian kepada masyarakat ditujukan untuk "Pembangunan Infrastruktur Jaringan Internet Murah Berbasis Gelombang Radio di Dusun Tanggulangin Desa Margosari Kecamatan Limbangan Kabupaten Kendal". Hasil dari kegiatan ini, masyarakat sekitar mendapatkan kemudahan dalam mengakses internet dengan biaya yang lebih terjangkau.

\section{PENDAHULUAN}

Pandemi Covid-19 terjadi sudah lebih dari satu tahun ini dan hampir semua sektor terdampak. Berdasarkan data perkembangan penyebaran virus Covid-19 yang terjadi di Provinsi Jawa Tengah pembaruan tanggal 30 Agustus 2021 dari halaman website resmi Satuan Tugas Penanganan Covid-19, kasus meninggal dunia banyak dialami oleh penduduk usia $\geqslant 60$ tahun, bahkan 2,5\% dari anak berumur 0-5 tahun positif Covid-19. Kebijakan social distancing (misalnya dengan mengurangi atau menghindari aktivitas yang menimbulkan keramaian) maupun physical distancing (menjaga jarak secara fisik) dikeluarkan Pemerintah untuk mengurangi dampak persebaran virus ini. Dalam dunia pendidikan, Pemerintah menghimbau kepada seluruh institusi pendidikan untuk melakukan kegiatan belajar mengajar secara online di semua jenjang pendidikan. Interaksi antara pendidik dengan peserta didik dilakukan secara virtual melalui berbagai macam aplikasi.

Pelaksanaan kegiatan belajar mengajar secara online membutuhkan sarana penunjang seperti komputer, laptop, smartphone atau tablet. Sarana yang tidak kalah penting yaitu ketersediaan jaringan internet. Jumlah penduduk yang berstatus pelajar atau mahasiswa di Desa Margosari cukup banyak, yaitu 35,1\% dari jumlah total penduduk, data ini bersumber dari halaman website resmi Sistem Informasi Desa Jawa Tengah. Dengan demikian, kebutuhan akses internet untuk kegiatan belajar mengajar secara online cukup tinggi. Berdasarkan data dan informasi yang diperoleh mengenai kondisi lingkungan dan komposisi pekerjaan penduduk, permasalahan yang muncul terkait akses internet sebagai berikut: 
a. ISP (Internet Service Provider) terdekat dengan lokasi sasaran berjarak 6 (enam) km, sehingga sinyal tidak stabil.

b. Meskipun di lokasi sudah terdapat layanan akses internet yang disediakan oleh provider, biaya yang dikenakan masih dirasa cukup mahal oleh masyarakat sekitar.

c. Pembangunan infrastruktur jaringan internet membutuhkan biaya yang cukup besar.

Pembangunan infrastruktur jaringan internet murah pada kegiatan pengabdian kepada masyarakat ini menggunakan jaringan nirkabel (wireless network) dengan memanfaatkan gelombang radio sebagai media transmisinya. Jaringan nirkabel (wireless network), yaitu sebuah jaringan tanpa media kabel untuk bertukar data atau informasi, tetapi menggunakan gelombang elektromagnetik untuk mengirimkan sinyal data atau informasi (Kadir, A., 2014). Secara umum, radio mempunyai kegunaan sebagai berikut (Indriyawati et al., 2011): a. Untuk memperjelas informasi atau pesan yang diterima; $b$. Untuk mengatasi keterbatasan tenaga, keterjangkauan daya indra serta keterbatasan ruang dan waktu. c. Menumbuhkan semangat belajar dan interaksi secara langsung ataupun tidak langsung diantara pendidik atau sumber pembelajaran dengan peserta didik. d. Peserta didik dapat belajar secara mandiri melalui sumber pembelajaran yang tersedia di internet. e. Memberikan persepsi dan rangsangan yang sama serta menyamakan pengalaman.

Adapun kelebihan dari penggunaan jaringan wireless, antara lain (Priyambodo, dalam Adisti et al., 2012): a. Jaringan wireless mendukung portabilitas; b. Perangkatnya relatif murah; c. Anggaran biaya untuk pemeliharaan relatif murah; d. Tidak memerlukan tempat yang luas untuk penempatan infrastruktur karena dimensinya kecil; e. Kemudahan untuk dipindah atau direlokasi; f. Pembangunan tidak memakan waktu lama. Disamping kelebihan, terdapat beberapa kelemahan dari penggunaan jaringan wireless, antara lain (Priyambodo, dalam Adisti et al., 2012): a. Data atau informasi yang dikirim melalui jaringan wireless dengan media frekuensi radio kurang aman karena dapat diakses secara bebas; b. Biaya peralatan yang mahal; c. Mudah terjadi interferensi; d. Kapasitas jaringan tidak terlalu besar.

Tahapan kegiatan pengabdian kepada masyarakat yang dilakukan ini diawali dengan melakukan proses survey untuk mendapatkan gambaran kondisi lingkungan dan masyarakat setempat, yakni yang berkaitan dengan kemampuan masyarakat dalam mengeluarkan biaya untuk akses internet dan ketersediaan jaringan internet di lokasi. Kemudian dilakukan pembangunan infrastruktur jaringan internet di lokasi. Setelah proses pembangunan infrastruktur jaringan internet selesai, dilakukan pembinaan dan penyuluhan kepada masyarakat di lokasi kegiatan. Di tahap akhir akan dilakukan evaluasi secara bertahap terhadap pelaksanaan kegiatan pengabdian kepada masyarakat ini. Perlu diketahui bahwa dalam kegiatan ini, perguruan tinggi dalam hal ini Institut Teknologi dan Bisnis Semarang berperan dalam mendanai dan memfasilitasi pembangunan jaringan infrastruktur internet murah yang menggandeng provider internet yang sudah ada yaitu CV 99 Net untuk pengelolaannya. 
Manfaat yang diharapkan dari pembangunan infrastruktur jaringan internet murah ini, antara lain: masyarakat bisa mengakses internet dengan biaya yang lebih murah, memberikan kontribusi pada bidang pendidikan dalam memfasilitasi sarana kegiatan belajar mengajar yang dilakukan secara online, membantu Pemerintah dalam perluasan jaringan internet murah khususnya di Provinsi Jawa Tengah.

\section{METODE PELAKSANAAN}

\section{Jaringan Komputer}

Hubungan antara dua atau lebih komputer (simpul) yang berfungsi untuk melakukan pertukaran data adalah definisi dari jaringan komputer menurut Abdul Kadir (2014). Adanya jaringan komputer dapat memberikan manfaat sebagai berikut (Kadir, A., 2014): a. Dapat meningkatkan komunikasi dan ketersediaan informasi; b. Memberikan kemudahan dalam berbagi sumber daya; c. Memberikan kemudahan berbagai file; d. Memberikan fleksibilitas kepada para pengguna dalam mengeksplorasi dan mengakses informasi yang dibutuhkan; e. Jaringan komputer merupakan sistem yang murah jika dibandingkan dengan informasi yang diperoleh dan dibagikan ke pengguna lain yang sangat bermanfaat; f. Efisiensi biaya melalui jaringan computer; g. Dapat meningkatkan kapasitas penyimpanan yang dibutuhkan.

Jaringan menurut rentang geografisnya dibedakan menjadi (Kadir, A., 2014): a. LAN (Local Area Network); b. Merupakan jaringan komputer yang masih berada dalam lingkup satu ruangan atau gedung atau beberapa gedung yang masih dalam satu area (berdekatan); c. MAN (Metropolitan Area Network); d. Merupakan jaringan komputer yang masih berada pada lingkup satu kota atau berjarak sekitar 10-45 kilometer; e. WAN (Wide Area Network); f. Merupakan jairngan komputer yang mempunyai cakupan antar kota, provinsi bahkan benua.

\section{Topologi Jaringan}

Menurut Kadir (2014), topologi jaringan adalah rangkaian fisik komputer dalam suatu jaringan. Topologi jaringan secara garis besar dibagi menjadi (Kadir, A., 2014):

a. Topologi Bus

Pada topologi bus, komputer yang ada terhubung melalui suatu kabel yang dinamakan bus. Adapun kelebihan dari topologi ini, antara lain:

- Apabila bus atau kabel utama terputus, maka seluruh komputer tidak dapat terhubung.

- Apabila bus atau kabel utama berukuran sangat panjang, jika mengalami gangguan maka proses pencarian pemicu gangguan sangat sulit dilakukan.

- Apabila terdapat banyak komputer yang sedang aktif, akan sering terjadi benturan sehingga dapat menyebabkan kecepatan pengiriman data atau informasi menjadi lambat.

Keunggulan dari topologi bus ini, yaitu:

- Proses instalasi jaringan mudah.

- Anggaran biaya yang dibutuhkan sedikit. 
b. Topologi Cincin (Ring)

Topologi cincin (ring) mirip dengan topologi bus. Data atau informasi yang ditransfer dari sebuah komputer akan diteruskan ke media transmisi melalui komputer ke komputer selanjutnya. Adapun kekurangan dari topologi ini yaitu jika ada satu komputer (simpul) yang mengalami kegagalan, akan menyebabkan terputusnya semua hubungan komputer tersebut.

c. Topologi Bintang (Star)

Topologi star mempunyai komponen yang berfungsi sebagai pusat kontrol, semua komputer (simpul) yang berkomunikasi akan selalu melewati pusat kontrol. Pusat kontrol dapat berbentuk switch atau hub. Beberapa kelebihan dari topologi ini, antara lain:

- Mudah dihubungkan dan dalam pengelolaannya.

- Kegagalan yang dialami oleh sebuah komputer (simpul) tidak akan mempengaruhi semua jaringan.

\section{Interkoneksi Antarjaringan}

Menurut Kadir (2014), definisi interkoneksi antarjaringan adalah hubungan atau koneksi antara dua atau lebih jaringan yang memerlukan peralatan khusus. Peralatan yang digunakan dalam interkoneksi antar jaringan, yaitu (Kadir, A., 2014):

a. Repeater

b. Fungsi dari repeater adalah untuk memperbaiki isyarat atau kode yang agak rusak dan biasanya jangkauan jaringan pada topologi bus diperpanjang menggunakan repeater.

c. Bridge

Peralatan ini dibutuhkan ketika dua buah jaringan yang memiliki tipe sama tetapi dikehendaki jalur lokal tiap-tiap jaringan agar tidak saling terpengaruh satu sama lain.

d. Router

Untuk menghubungan dua buah jaringan yang berbeda tipe digunakan router.

e. Gateway

Peralatan yang digunakan untuk menghubungkan dua jaringan dengan protokol yang berbeda.

f. Brouter

Peralatan yang bisa berfungsi sebagai bridge dan router.

\section{Transmisi Data}

Transmisi data merupakan proses transfer data dari pengirim ke penerima melalui media transmisi dan data yang ditransmisikan biasanya berupa data digital (Noersasongko, E. et al., 2019). Terdapat dua teknik pengiriman transmisi data, yaitu (Noersasongko, E. et al., 2019):
a. Transmisi Data Serial
Pengiriman data yang dilakukan secara satu per satu. Bit data hanya akan dikirimkan jika bit data sebelumnya sudah diterima.
b. Transmisi Data Paralel 
Pengiriman data yang dilakukan secara sekaligus melalui beberapa saluran pada saat bersamaan, sehingga pengiriman data lebih cepat.

\section{Media Transmisi Data}

Menurut Noersasongko, et al. (2019), media transmisi data merupakan jalur fisik antara pemancar dan penerima data. Beberapa media transmisi data, antara lain (Noersasongko, E. et al., 2019): kabel untiran, kabel koaksial, kabel serat optic, Gelombang radio, Telepon seluler, Gelombang mikro, Satelit.

\section{Internet}

Edi Noersasongko, et al. (2019) dalam bukunya mendefinisikan internet merupakan suatu jaringan komputer yang di dalamnya terdapat berbagai macam ukuran jaringan komputer di seluruh dunia yang dimulai dari komputer personal (PC), jaringan berukuran kecil sampai berukuran besar yang menjadi tulang punggung (backbone). Beberapa alasan mengapa internet menjadi populer, antara lain (Noersasongko, E. et al., 2019):

a. Komputer akan tetap terhubung satu sama lain meskipun jalur dalam keadaan sibuk atau tidak.

b. Bebas, yang berarti tidak tergantung pada vendor atau perusahaan apapun, dengan kata lain tidak ada kontrol terpusat.

c. Biaya komunikasi sangat murah, meskipun komunikasi dilakukan antarnegara, benua bahkan di dunia.

d. Informasi banyak tersedia dan akses sangat mudah dan cepat.

\section{METODE PELAKSANAAN}

Adapun tahapan metodologi pelaksanaan dari kegiatan pengabdian kepada masyarakat ini, yaitu:

a. Survey

- Survey lokasi untuk memastikan sudut dan ketinggian untuk pemasangan antena agar bisa diperoleh sinyal terbaik serta untuk menentukan jalur untuk pemasangan koneksi internet yang akan dibangun.

- Penentuan dan persiapan lokasi pembuatan pondasi sementara untuk pendirian tower antena.

- Pada kegiatan ini dilakukan survey untuk mendapatkan gambaran kondisi lingkungan dan masyarakat setempat, yakni yang berkaitan dengan kemampuan masyarakat dalam mengeluarkan biaya untuk akses internet dan ketersediaan jaringan internet di lokasi.

- Diskusi awal dengan mitra provider internet CV 99 Net perihal kerja sama yang akan dilakukan.

b. Persiapan

- Penandatanganan kerja sama dengan mitra provider internet berkaitan dengan pembagian pekerjaan.

- Pengadaan dana yang dibutuhkan.

- Pengadaan peralatan dan material yang dibutuhkan untuk pembangunan 
infrastruktur jaringan internet.

- Persiapan materi untuk memberikan pembinaan dan penyuluhan kepada masyarakat di lokasi kegiatan.

c. Pelaksanaan Kegiatan

Tahapan pelaksanaan kegiatan dilakukan selama dua bulan, kegiatan tersebut meliputi:

1) Pembangunan infrastruktur jaringan internet. Pada tahapan ini dilakukan:

- Pemasangan perangkat seperti wireless access point, kabel fiber optik dan kabel FTP.

- Konfigurasi access point.

- Pengkabelan jaringan lokal.

- Pemasangan dan konfigurasi wireless access point lokal.

- Testing koneksi internet.

2) Pengecekan jaringan internet. Pada tahapan ini dilakukan:

- Proses pengecekan kualitas sinyal dari kabel.

- Memaksimalkan kualitas sinyal dari kabel.

- Pengecekan kualitas internet.

- Pengecekan kelayakan instalasi dan perangkat yang digunakan.

3) Pembinaan dan penyuluhan kepada masyarakat di lokasi kegiatan. Pada kegiatan pembinaan dan penyuluhan, masyarakat diberikan pemahaman dan pengetahuan tentang:

- Penggunaan internet melalui jaringan kabel atau wireless access point yang telah dibangun.

- Pengenalan dan pengetahuan tentang internet dan layanan yang ada di dalamnya.

- Manfaat internet dalam berbagai bidang kehidupan.

- Cara maintenance (perawatan) dan troubleshooting jaringan dan perangkat yang digunakan.

- Pemberian pengarahan kepada warga tentang perlunya pengawasan penggunaan internet pada anak-anak di bawah umur.

d. Evaluasi

Memastikan ketercapaian tujuan dan keberhasilan dari kegiatan yang telah dilakukan, yaitu:

- Masyarakat setempat sudah tidak mengalami kesulitan untuk mengakses internet terlebih yang berkaitan dengan masalah biaya.

- Kegiatan belajar mengajar yang dilakukan secara online di lokasi dapat berjalan dengan lancar.

- Proses evaluasi ini akan dilakukan secara bertahap. 


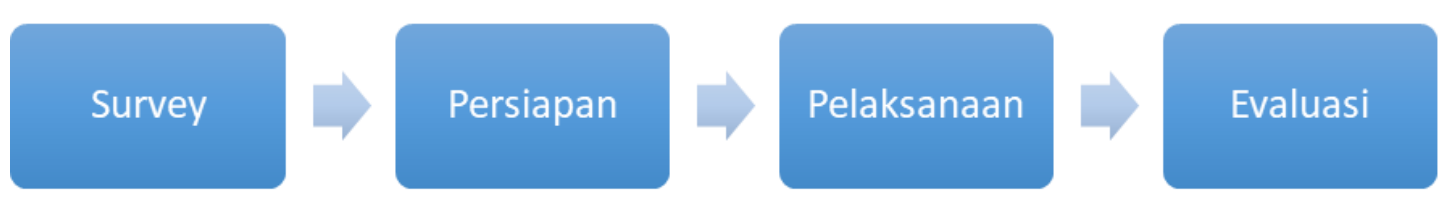

Gambar 1. Metode Pelaksanaan

\section{HASIL DAN PEMBAHASAN}

\section{Pembangunan Infrastruktur Jaringan Internet}

Dasar pemilihan lokasi pembangunan infrastruktur jaringan internet murah sesuai dengan hasil survey yang telah dilakukan oleh tim Pengabdian. Di mana yang menjadi bahan pertimbangannya adalah dari data yang diperoleh dari halaman website resmi Sistem Informasi Desa Jawa Tengah, jumlah penduduk yang berstatus pelajar atau mahasiswa di Desa Margosari cukup banyak yaitu 35,1\% dari jumlah total penduduk, dengan demikian kebutuhan akses internet untuk kegiatan belajar mengajar secara online cukup tinggi, masyarakat setempat keberatan dengan biaya layanan akses internet yang ditawarkan oleh provider yang sudah ada dan untuk membangun infrastruktur jaringan internet sendiri membutuhkan biaya yang cukup besar. Selain itu, ISP (Internet Service Provider) terdekat dengan Dusun Tanggulangin, Desa Margosari berjarak 6 (enam) km, sehingga sinyal yang sampai ke daerah sasaran tidak stabil. Dari sekian banyak provider yang bersedia untuk bekerja sama dalam penyediaan koneksi internet dan memberikan program gratis selama 1 (satu) bulan serta biaya berlangganan yang murah untuk mendukung pelaksanaan program pengabdian ini adalah CV 99 Net.

Tahap pembangunan infrastruktur jaringan internet di Dusun Tanggulangin Desa Margosari Kecamatan Limbangan Kabupaten Kendal dilakukan setelah melalui tahap persiapan. Pada tahap persiapan telah dilakukan kesepakatan dengan mitra provider internet mengenai pembagian scope pekerjaan. Dari diskusi tersebut diperoleh kesepakatan bahwa pihak Institut Teknologi dan Bisnis Semarang mendanai dan memfasilitasi pembangunan jaringan infrastruktur internet murah sedangkan mitra provider internet yakni CV 99 Net yang nantinya sebagai pengelola infrastruktur jaringan internet yang telah dibangun tersebut. Tim pelaksana kegiatan menyusun anggaran yang dibutuhkan mulai dari kegiatan pembangunan infrastruktur jaringan internet sampai dengan kegiatan tersebut selesai. Kemudian persiapan peralatan dan material yang dibutuhkan serta mempersiapkan materi tentang jaringan komputer dan internet yang akan digunakan dalam pembinaan dan penyuluhan masyarakat setempat.

Pada pembangunan infrastruktur jaringan internet ini ditanam sebuah tower pipa yang terbuat dari besi untuk menopang perangkat jaringan seperti antena dan kabel. Antena yang digunakan adalah AirGrid Ubiquiti, sedangkan kabel yang ditarik dari tower antena adalah kabel fiber optik (FO). Terdapat 15 (lima belas) titik hubung pada jaringan internet yang dibangun ini. Pada setiap titik tersebut dipasang perangkat yang ditempelkan pada bangunan milik warga setempat antara lain HTB media converter, fiber optic side A side B dan router agar dapat terhubung ke tower antena. Untuk penempatan rak perangkat ada di salah satu rumah warga di mana tower antena terpasang. Setelah jaringan internet terbangun, dilakukan proses pengecekan atau 
evaluasi. Di sini dilakukan proses pengecekan terkait kualitas sinyal, kualitas internet dan kelayakan instalasi jaringan yang dibangun serta perangkat yang digunakan. Adapun komponen perangkat yang digunakan dalam pembangunan infrastruktur jaringan internet ini antara lain:

Tabel 1. Komponen Perangkat yang Digunakan

Komponen Perangkat

\begin{tabular}{|c|c|}
\hline Tower antena & Penempatan antena dan kabel outdoor \\
\hline Antena AirGrid Ubiquiti & $\begin{array}{l}\text { Menerima dan memancarkan sinyal dari jaringan wireless } \\
\text { terdekat. }\end{array}$ \\
\hline Router & $\begin{array}{l}\text { Menghubungkan beberapa jaringan, mengirimkan data atau } \\
\text { informasi dari suatu jaringan dan sebagai penghubung } \\
\text { jaringan lokal. }\end{array}$ \\
\hline Mikrotik & Mengatur konfigurasi jaringan. \\
\hline $\begin{array}{lll}\text { Kabel UTP } & \text { (Unshielded Twisted } \\
\text { Pair) } & & \\
\end{array}$ & $\begin{array}{l}\text { Penghubung berbagai perangkat yang terkoneksi dalam suatu } \\
\text { jaringan. }\end{array}$ \\
\hline Konektor RJ45 & $\begin{array}{l}\text { Menghubungkan kabel ethernet (penghubung kabel dengan } \\
\text { jaringan komputer) yang dipakai pada jaringan. }\end{array}$ \\
\hline Kabel FO (Fiber Optik) & $\begin{array}{l}\text { Sebagai penghubung antar jaringan, mentransfer data dengan } \\
\text { kecepatan tinggi. }\end{array}$ \\
\hline Kabel FTP (Foiled Twisted Pair) & $\begin{array}{l}\text { Penghubung berbagai perangkat yang terkoneksi dalam suatu } \\
\text { jaringan, namun spesifikasinya lebih bagus dari kabel UTP } \\
\text { dan lebih tahan terhadap interferen gelombang } \\
\text { elektromagnet. }\end{array}$ \\
\hline Konektor Fiber Optik & $\begin{array}{l}\text { Penghubung antara kabel fiber optik dengan transmitter } \\
\text { maupun receiver. }\end{array}$ \\
\hline Media Konverter (Converter Media) & $\begin{array}{l}\text { Perangkat jaringan internet sederhana sebagai penghubung } \\
\text { media yang berbeda, misalnya kabel fiber optik dengan kabel } \\
\text { UTP. }\end{array}$ \\
\hline Switch & $\begin{array}{l}\text { Penghubung perangkat komputer dalam pertukaran paket } \\
\text { seperti menerima, memproses dan meneruskan data ke } \\
\text { perangkat yang lain. }\end{array}$ \\
\hline & $\begin{array}{l}\text { Rak Transmisi } \\
\text { Rumah Warga } \\
\quad \text { (Utama) }\end{array}$ \\
\hline Outdoor TPLink & Outdoor TPLink \\
\hline 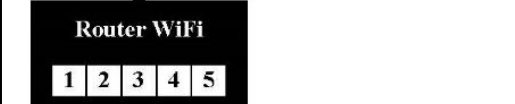 & \begin{tabular}{l|l|l|l|l|}
\multicolumn{5}{|c|}{ Router WiFi } \\
\multicolumn{11}{|l|}{} & 12 & 13 & 14 & 15 \\
\end{tabular} \\
\hline
\end{tabular}




\section{Gambar 2. Penempatan Perangkat Jaringan}

Masyarakat Dusun Tanggulangin, Desa Margosari dapat memanfaatkan infrastruktur jaringan internet ini dengan cara berlangganan jaringan internet pada provider yang telah ditunjukan sebagai pengelola oleh Institut Teknologi dan Bisnis Semarang. Dari segi biaya berlangganan jauh lebih murah dibandingkan dengan provider yang sudah ada, sehingga tidak memberatkan masyarakat setempat untuk berlangganan jaringan internet.

\section{Pembinaan dan Penyuluhan}

Dalam kegiatan pembinaan dan penyuluhan ini, tim memberikan pengetahuan kepada masyarakat setempat tentang jaringan internet dan manfaatnya. Kegiatan pembinaan dan penyuluhan ini telah dilaksanakan pada hari Selasa, 3 Agustus 2021 di Balai Desa Margosari, Kecamatan Limbangan, Kabupaten Kendal dan dihadiri oleh Kepala Desa dan warga Desa Margosari, perwakilan dari CV 99 serta Institut Teknologi dan Bisnis Semarang. Adapun kegiatan pembinaan dan penyuluhan ini dilakukan dengan memaparkan materi mengenai penggunaan internet melalui jaringan kabel atau wireless access point yang telah dibangun, pengenalan dan pengetahuan tentang internet dan layanan yang ada di dalamnya, manfaat internet dalam berbagai bidang kehidupan serta cara maintenance (perawatan) dan troubleshooting jaringan dan perangkat yang digunakan, melakukan pembelajaran terkait pengaturan dan penggunaan internet, pemberian pengarahan kepada warga tentang perlunya pengawasan penggunaan internet pada anak-anak di bawah umur, selain itu juga diadakan sesi tanya jawab dengan warga setempat mengenai hal-hal yang berkaitan dengan jaringan internet. Dengan diadakannya kegiatan pembinaan dan penyuluhan ini, diharapkan masyarakat mengetahui pentingnya jaringan internet dan menambah wawasan atau pengetahuan mereka tentang teknologi saat ini serta dapat melakukan maintenance dan troubleshoot jaringan internet secara mandiri.

\section{Evaluasi}

Tahapan terakhir dari kegiatan ini adalah proses evaluasi. Dimana tim pelaksana melakukan evaluasi terhadap pembangunan infrastruktur jaringan internet itu sendiri dan evaluasi apakah tujuan dari kegiatan pengabdian kepada masyarakat ini sudah tercapai, yaitu:

- Masyarakat setempat sudah tidak mengalami kesulitan untuk mengakses internet terlebih yang berkaitan dengan masalah biaya.

- Kegiatan belajar mengajar yang dilakukan secara online di lokasi dapat berjalan dengan lancar.

Agar hasil dari kegiatan pengabdian kepada masyarakat ini lebih optimal, maka proses evaluasi dilakukan secara bertahap, sehingga tim pelaksana kegiatan bisa mendapatkan masukan dari masyarakat setempat terkait adanya jaringan internet yang sudah dibangun.

\section{SIMPULAN}

Beberapa kesimpulan yang diperoleh dari hasil pelaksanaan kegiatan adalah sebagai berikut: 
a. Masyarakat setempat yakni masyarakat Dusun Tanggulangin Desa Margosari Kecamatan Limbangan Kabupaten Kendal menyambut baik adanya pelaksanaan kegiatan ini.

b. Hasil dari pelaksanaan kegiatan pengabdian masyarakat ini yaitu tersedianya jaringan internet murah bagi masyarakat setempat.

c. Dengan adanya kegiatan ini dapat turut membantu Pemerintah dalam memperluas infrastruktur jaringan internet murah.

d. Kegiatan belajar mengajar yang dilakukan secara online di Dusun Tanggulangin Desa Margosari Kecamatan Limbangan Kabupaten Kendal sudah tidak terkendala dengan keterbatasan jaringan internet dan biaya yang dibebankan untuk mengakses internet.

\section{DAFTAR PUSTAKA}

Adisti, A. R. dan Heriyanto. 2011. Hubungan Pemanfaatan Teknologi Wi-Fi dengan Tingkat Kunjungan Pemustaka di UPT Perpustakaan Politeknik Negeri Semarang. Jurnal Ilmu Perpustakaan, Vol. 1 (1), 60 - 66.

Dinas Pemberdayaan Masyarakat, Desa, Kependudukan dan Pencatatan Sipil Provinsi Jawa Tengah. 2020. Komposisi Pekerjaan Penduduk Desa Margosari. Diakses pada 31 Agustus 2021, dari https://sidesa.jatengprov.go.id/desa/.

Indriyawati, H. dan Suprayogi, M. S. 2011. Pengembangan Radio Online sebagai Pemanfaatan Teknologi Informasi dan Komunikasi untuk Pengembangan Potensi Mahasiswa di Lingkungan Universitas Semarang. Jurnal Transformatika, Vol. 9 (1), $37-45$.

Kadir, Abdul. Pengenalan Sistem Informasi, Edisi Revisi. Yogyakarta: Andi Offset. 2014.

Mufadhol. Networking dan Internet. Semarang: Semarang University Press. 2008.

Noersasongko, Edi., Andono, Pulung Nurtantio dan Sutojo, T. Pengantar Teknologi Informasi. Semarang: Andi Offset. 2019.

Satuan Tugas Penanganan Covid-19. (2021). Peta Sebaran Covid-19 Provinsi Jawa Tengah. Diakses pada 31 Agustus 2021, dari https://covid19.go.id/. 


\section{LAMPIRAN}

Foto Pelaksanaan Pembangunan Infrastruktur Jaringan Internet
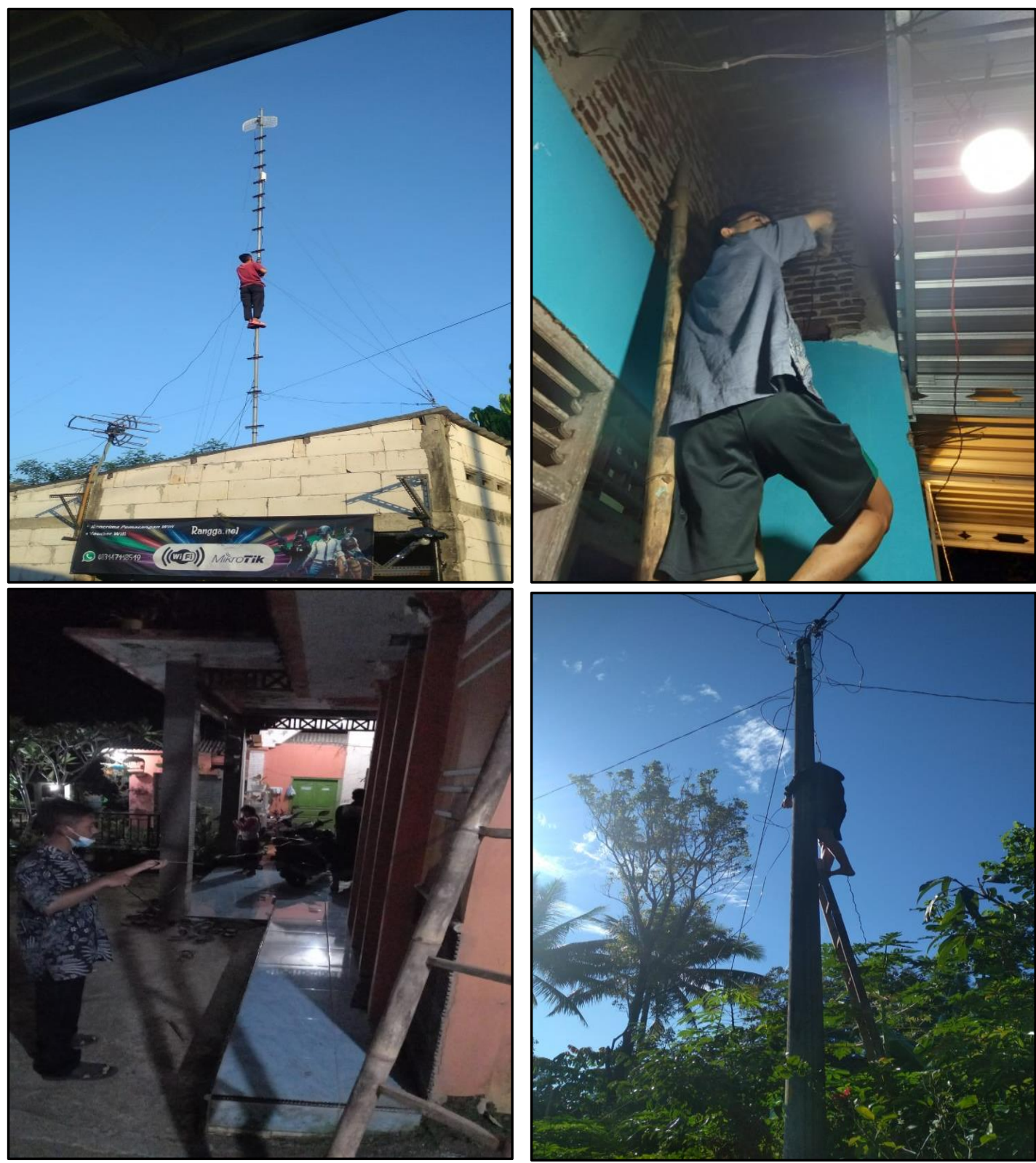
Pembangunan Infrastruktur Jaringan Internet Murah Berbasis Gelombang Radio di Dusun Tanggulangin Desa Margosari Kecamatan Limbangan Kabupaten Kendal (Bambang Widjanarko Susilo, Priyo Nugroho Adi, Siska Narulita, Andreas Tigor Oktaga, Priyo Wibowo)

\section{Foto Pelaksanaan Pembangunan Infrastruktur Jaringan Internet}
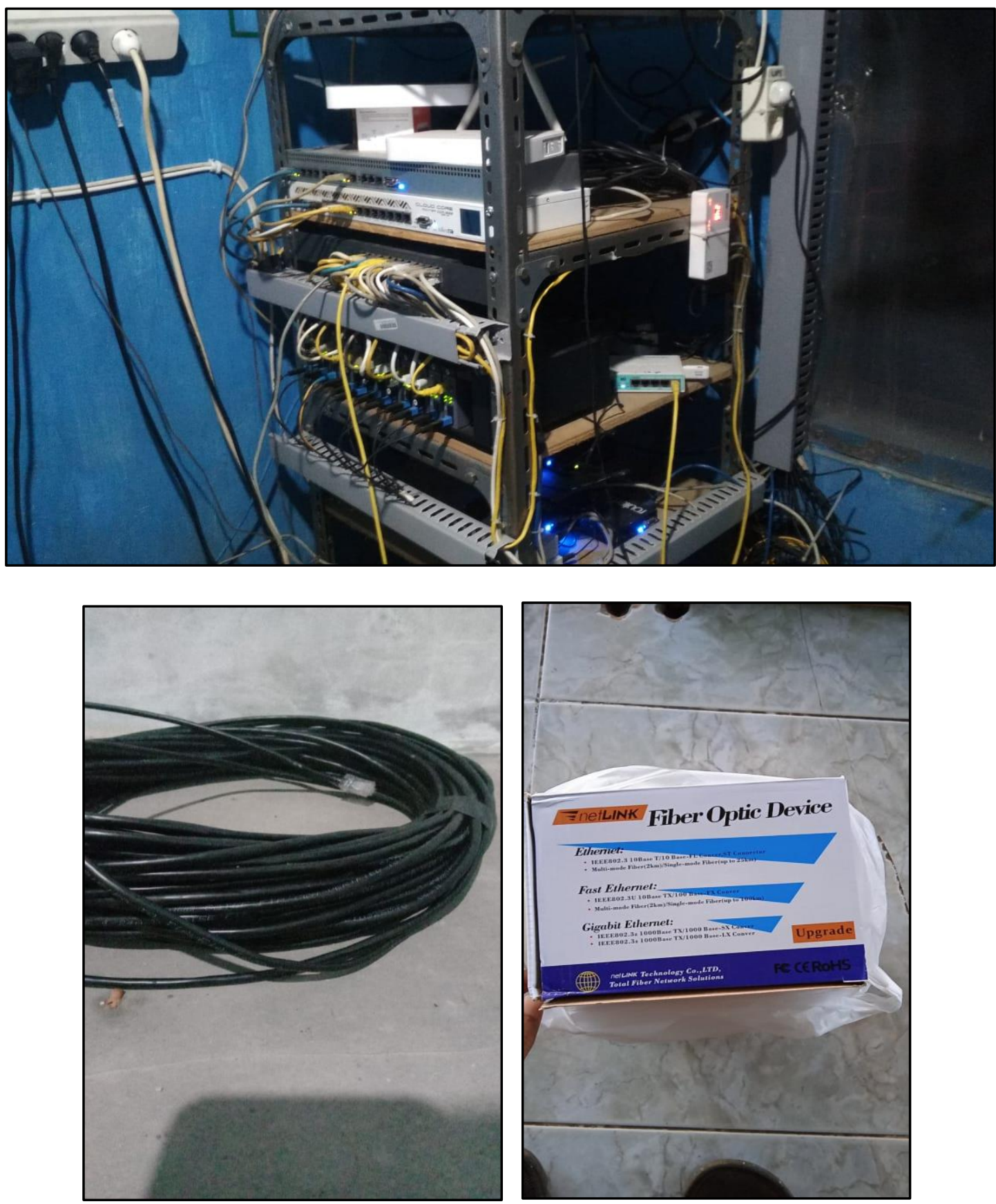


\section{Foto Pelaksanaan Pembinaan dan Penyuluhan}
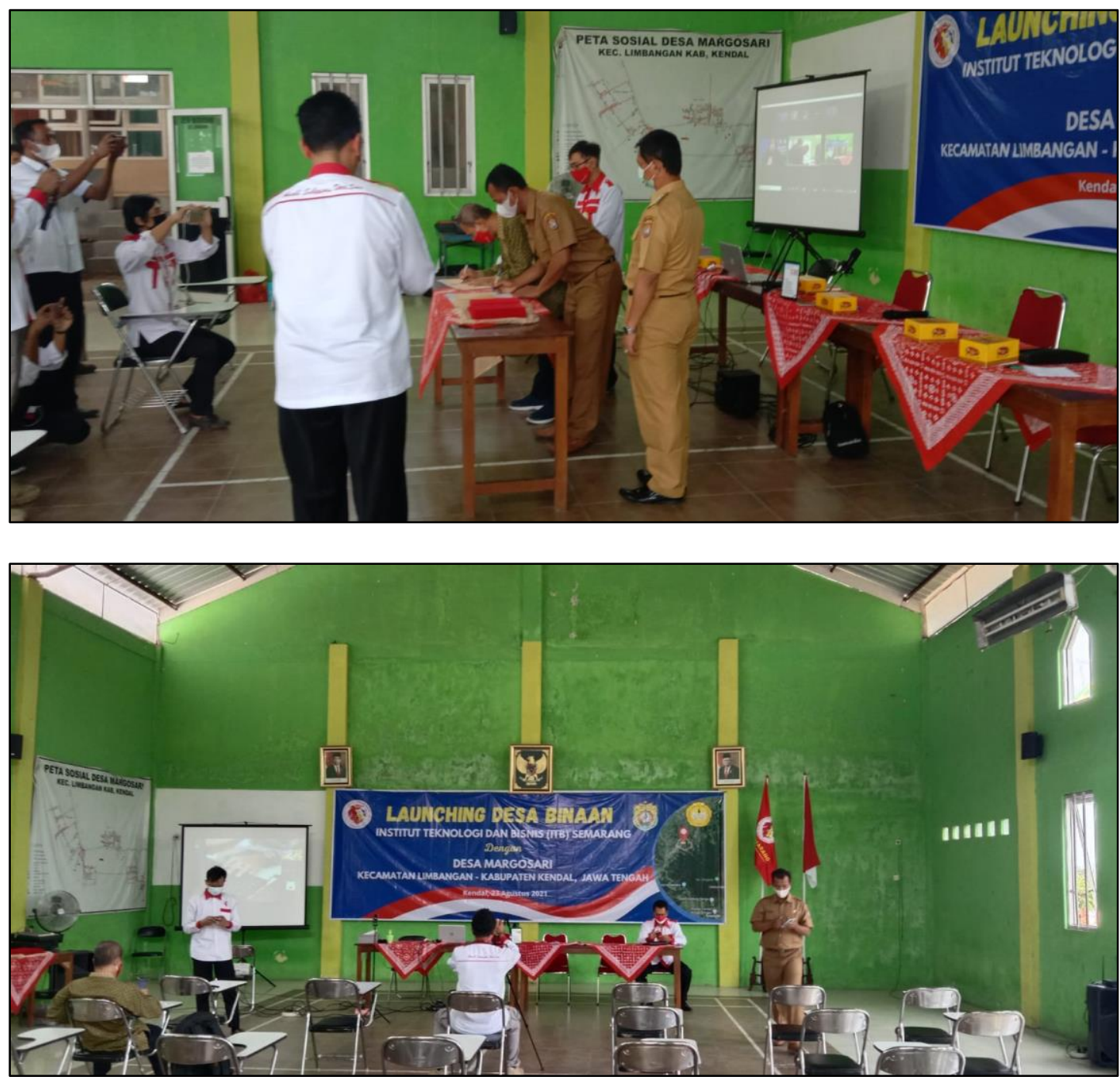